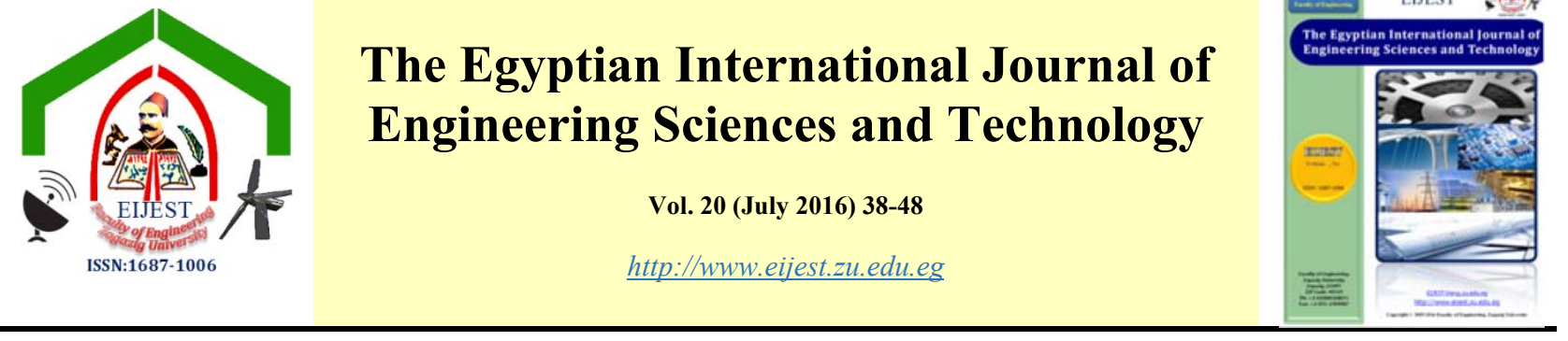

\title{
Evaluating the Performance of Order Fulfillment Process in Supply Chain
}

\author{
Abdel Nasser H. Zaied ${ }^{\mathrm{a}}$, Mohamed A. Mansour ${ }^{\mathrm{b}}$, and Mohab A. Mostafa ${ }^{\mathrm{b} *}$ \\ ${ }^{a}$ Professor, Dean, collage of computer and informatics, Zagazig University, Zagazig, Egypt \\ ${ }^{b}$ Department of Industrial Engineering, Faculty of Engineering, Zagazig University, Zagazig, Egypt
}

\begin{tabular}{|c|c|}
\hline A R T I C L E I N F O & A B S T RA C T \\
\hline $\begin{array}{l}\text { Article history: } \\
\text { Received: } 21 \text { March } 2016 \\
\text { Received in revised form: } 19 \\
\text { June } 2016 \\
\text { Accepted: } 28 \text { June } 2016 \\
\text { Available online: } 14 \text { July } \\
2016\end{array}$ & $\begin{array}{l}\text { Supply chain management became a major component of competitive strategy to } \\
\text { enhance organizational productivity and profitability. It is stated that supply chain } \\
\text { performance measurement is an important step in developing supply chain. } \\
\text { Performance measurement has a substantial role to play in setting objectives, } \\
\text { evaluating performance, and determining future courses of actions. The order } \\
\text { fulfillment process specifies the particular steps regarding the flow of the customer }\end{array}$ \\
\hline $\begin{array}{l}\text { Keywords: } \\
\text { Supply Chain (SC) } \\
\text { Order Fulfillment } \\
\text { Performance Measurement } \\
\text { Supply Chain Management } \\
\text { (SCM) } \\
\text { Metrics } \\
\text { Framework. }\end{array}$ & $\begin{array}{l}\text { processed, manufactured, documented, picked, delivered and also how post- } \\
\text { delivery is handled, so it is considered the main process to integrate and manage } \\
\text { supply chain. The purpose of this study is to evaluate the performance of the order } \\
\text { fulfillment process through a developed measurement framework. A review of the } \\
\text { current concepts of supply chain management and the related literature to supply } \\
\text { chain performance measurement is performed. The measurement framework is } \\
\text { divided into two categories of measures that evaluate the performance of order } \\
\text { fulfillment activities and the accuracy of the delivered orders respectively. A survey } \\
\text { is conducted through a questionnaire to give a weight for the measures of each } \\
\text { category. Objectives Matrix tool is applied to each category to obtain an overall } \\
\text { performance index for each category. A case study is made at a leading textile } \\
\text { company in Egypt. The results are two performance indices for order fulfillment; } \\
\text { the first one indicates the order fulfillment activity's performance and the other } \\
\text { indicates the delivered order's accuracy as the main intent of the order fulfillment } \\
\text { process. }\end{array}$ \\
\hline
\end{tabular}

* Corresponding author. Tel.:

E-mail address: eng_hoba007@hotmail.com 


\section{Introduction}

Supply Chain Management (SCM) is an effective business philosophy that has gained a tremendous amount of attention from academics, consultants, practitioners and business managers in the recent years in order to help enterprises to survive with continuous pressures and achieve the strategic goals [1].

Over the last decade of SCM evolution, a wide steady stream of research papers dealing with Supply Chain (SC) performance measurement has been published. As an essential management tool and the way to reach success, performance measurement enables supply chain to strategically manage and continuously control achieving objectives. It provides the necessary assistance for performance improvement in pursuit of supply chain excellence.

SCM represents a state-of-the-art management tool used to enhance overall customer satisfaction that is intended to improve competitiveness and profitability [2].

It addresses such modern business issues of longterm strategic alliance and supplier-buyer partnership, cross-organizational logistics management, joint planning and control of inventory, and information sharing (Beamon et al., 1998 [3], Chandra et al., 2000 [4]).

Cooper et al. (1997) [5] describe the conceptual framework of SCM, which consists of two major and closely related elements: business processes and the structure of the supply chain as shown in "Figure 1".
To achieve an efficient supply chain, performance evaluation of the entire supply chain is extremely important. Consequently, to design SC performance measurement models, considering the supply chain as a whole is really useful. The process of order fulfillment is what stimulates all the supply chain processes into action and involves many aspects of a company, from sales and marketing to order entry, transportation and finance. However, the core of the process involves the activities that take place in production and warehousing facilities: receiving and staging materials, planning and scheduling the order, producing the order, picking, packing and moving products into distribution and releasing the shipment (Pochampally et al., 2009) [6]. Companies simply cannot expect to delight customers unless those processes are efficient and coordinated. It is also the process where the customer interacts directly with the firm and as such has been highlighted as a key process for integrated performance measurement.

The rest of the paper is organized as follows: The next section describes a literature study of the available frameworks and points of view of the development of the supply chain performance measurement in the manufacturing industries. Section 3 describes the proposed performance measurement framework for order fulfillment process. Section 4 presents a case study on the proposed measurement framework. Section 5 shows the results and section 6 concludes the paper.

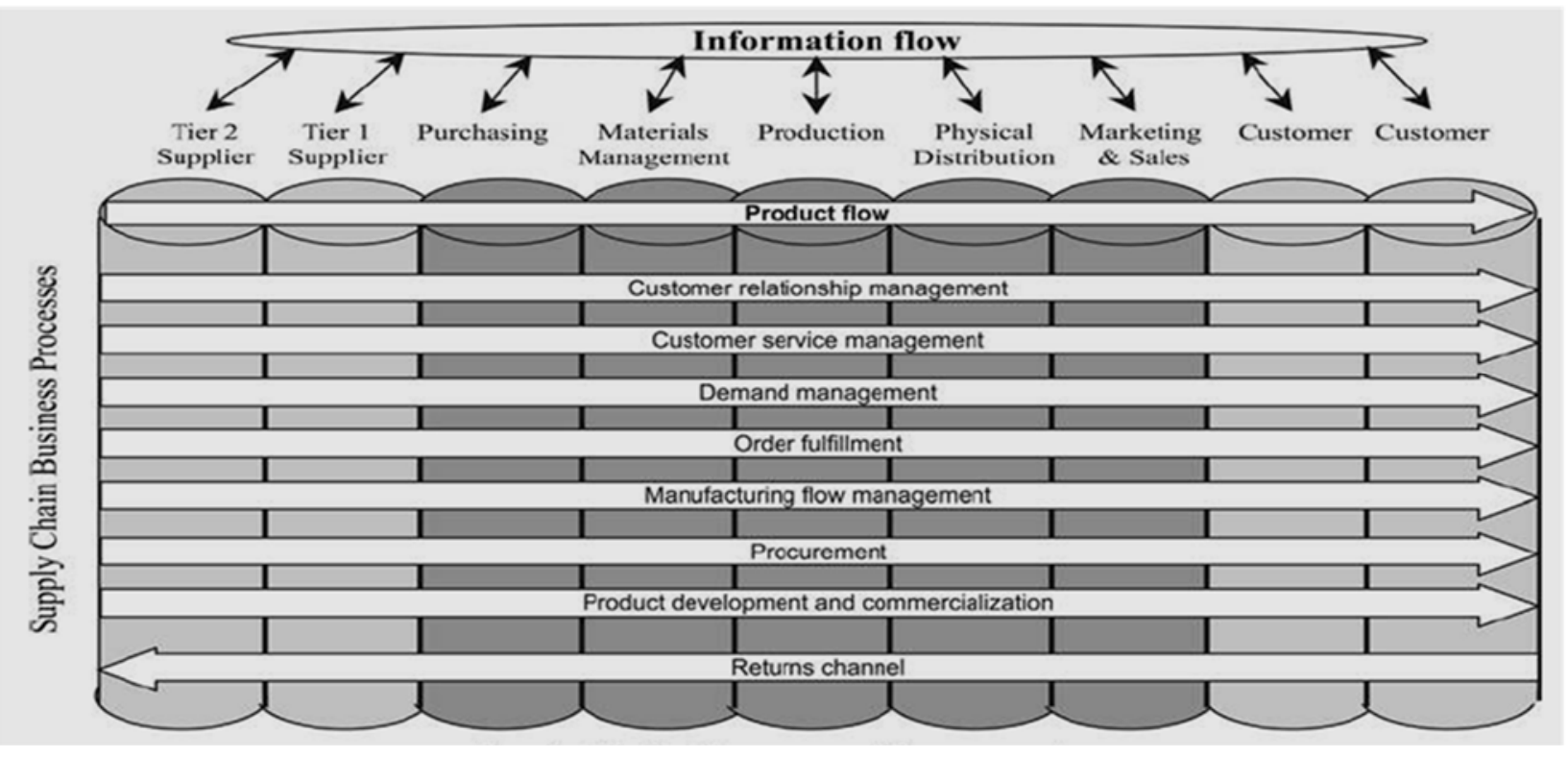

Fig. 1. Supply chain management components [5] 


\section{Literature Review}

The various literatures related to supply chain performance measurement frameworks are described in this section.

Beamon and Benita (1999) [7] identifies a performance framework for SCM, in which there are three groups of performance measures: resource measures, output measures and flexibility measures. The goal of the resource measures is a high level of efficiency and resource minimization and the purpose of the resource measures is the efficient resource management that is critical to profitability. The goal of output measure category is a high level of customer service. Flexibility goal is the ability to respond to the changing environment and purpose is that in an uncertain environment, supply chains must be able to respond to challenges that arise due to changes. Flexibility is categorized into four categories: volume flexibility, delivery flexibility, mix flexibility and new product flexibility [8].

Otto et al. (2003) [9] develop six perspectives for measuring the SCM capability which are system dynamics, operational research, logistics, marketing, organization and strategy. The idea of system dynamics is to manage trade-offs along the SC. The aim of operational research and information technology is to find optimal solutions with the given degrees of freedom. The logistic perspective target is to integrate generic processes sequentially, vertically and horizontally. Marketing approach is to segment customers and connect them with the right channel. Organization approach is to manage SC relations with measures of transaction costs, time to network, flexibility and density of relationships. The aim of the strategy perspective is to connect competencies and the ability to make profit [10].

Ghalayini et al. (1996) [11] state that the time performance measurement approach is a new strategic performance measure that should be used to promote improvement. In order to improve time performance, all operational performance measures should be measured, controlled and improved.

Toni et al. (2001) [12] indicate several measures of internal and external time performance. Internal times can be divided into run and set-up times on one hand and wait and move times on the other. Externally-perceived time performances can be divided into three parts: system times (including supplying, manufacturing and distribution lead times), delivery speed and delivery reliability (both from suppliers and to customers) and time to-market (or time required to develop a new product). These time measures presented are called time performance.

Chan et al. (2003a [13], 2003b [14]) show that SCM should be measured beyond the organizational boundaries rather than focusing locally. SCM can be categorized into six general processes which are linked together: supplying, inbound logistics, manufacturing, outbound logistics, marketing and sales and end customer processes. The processes of the main phases can be decomposed into subprocesses and activities, next assigning to each of them metrics related to cost, time, capability and outcome. "The performance of each process is the aggregated results of the performance of all its lowerhierarchy activities and sub-processes" (Chan et al. 2003a) [13]. Hence, by assessing activities in the lower hierarchies, one can gain an understanding of how they affect the top-level core processes.

Gunasekaran et al. (2004) [15] show that SCM performance measures divided into financial and non-financial measures. Top management needs the financial measures for management level decisions, but lower management and workers need the operational measures for daily business [8].

Shepherd and Hannes (2011) [16] distribute SC performance metrics to five $\mathrm{SC}$ processes which are plan, source, make, deliver and return. These metrics measure cost, time, quality, flexibility and innovativeness. Also, these metrics may be quantitative or qualitative.

Chan (2003) [17] presents an SCM performance measurement approach which consists of qualitative and quantitative measures. Quantitative measures are cost and resource utilization and qualitative measures are quality, flexibility, visibility, trust and innovativeness.

In 1996, Supply-Chain Council introduced the supply chain operations reference (SCOR) model, which is a global organization of firms interested in $\mathrm{SCM}$. The SCOR model is a business process reference model and it provides a framework that includes SC business processes, metrics, best practices, and technology features. The SCOR model advocates hundreds of performance metrics used in conjunction with five performance attributes presented by Supply Chain Council: $S C$ reliability, $S C$ responsiveness, $S C$ flexibility, $S C$ costs and $S C$ asset management (Theeranuphattana and Tang, 2008 [18], Najmi et al., 2013)[10]).

Kaplan and Norton (1992) [19] submit Balanced Scorecard BSC model to evaluate corporate performance in four types of perspectives: the financial, the internal business process, the customer as well as learning and growth. Financial perspective 
is the shareholders' view and customer perspective is a value-adding view. Internal perspective aims to promote efficiency and effectiveness in the business processes. This approach is also learning and growth perspective in future viewings. (Sillanpaa and Kess, 2011 [8], Kaplan and Norton, 2000 [20], Kaplan and Norton, 1996 [21], Neely et al., 2005 [22])

Bhagwat and Sharma (2007) [23] introduce a BSC approach: financial metrics, customer perspective, an internal business perspective as well as innovation and learning perspective. Financial performance measures the company's financial result. Evaluating customer perspective approach is to find out how customers see the business. Internal business perspective measures business processes that have the greatest impact on customer's satisfaction factors. Innovation and learning perspectives can win efficiency to firm's operative business in the future.

Although order fulfillment is regarded the main process to integrate and manage supply chain as it integrates all supply chain actions and specifies the particular steps regarding the flow of the customer orders through the supply chain, the surveyed researches did not focus on evaluating the order fulfillment performance.

\section{The Proposed Framework For Order Fulfillment Performance Measurement}

In this section, a framework for order fulfillment performance measurement is proposed. This framework is divided into two categories of measures:

The first Category (Internal Measures) is developed to evaluate the order fulfillment activities which represent an internal performance evaluation of a company.

The second Category (External Measures) is developed to evaluate the accuracy of delivered orders which considered an external performance evaluation to ensure customer satisfaction.

The measures are collected from several related references and assigned to each category. For each category of measures, the Objectives Matrix tool is used to combine these measures in one overall performance index. The first index indicates the overall performance of order fulfillment activities and the second index indicates the overall accuracy of the delivered orders.

The proposed framework for order fulfillment performance measurement is shown in "Figure 2".

\subsection{The first category (Internal measures)}

This category is developed according to processbased approach. The process-based approach defines a process as a set of integrated activities aimed at performing specific functions. These activities may be decomposed into detailed sub activities and then performance measures assigned to these sub activities. Chan et al. (2003a) [13] states the main advantages of adopting a process-based performance measurement which are:

- Evaluating the performance of each activity.

- Providing the opportunity of recognizing the problems in operations and taking a corrective action before these problems escalate.

- Facilitating linking with the operational strategies, identifying success, and testing the effect of strategies.

Two categories of measures used to evaluate order fulfillment performance - The first category (InternalMeasures) -The second category (ExternalMeasures)

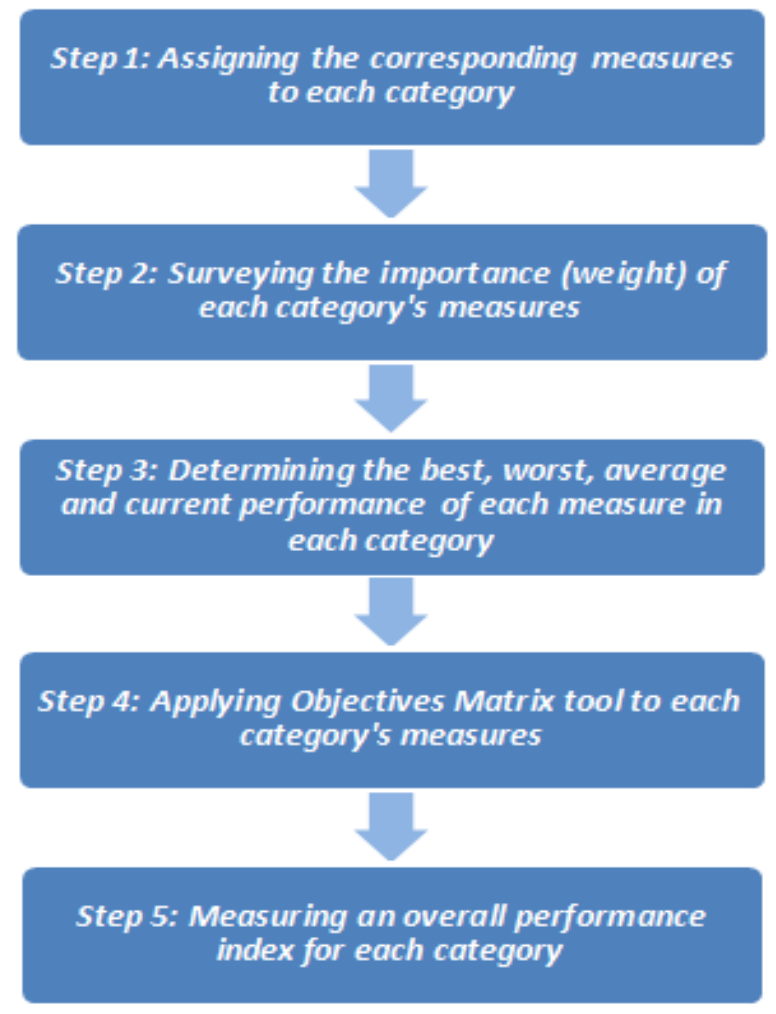

Fig. 2. The proposed measurment framework for order fulfillment process 
- Support in monitoring the progress.

- Assisting in directing the attention of the management to resource allocation.

- Enhancing communication of process objectives involved in the supply chain, thus increasing trust and common understanding.

According to (Amer et al., 2008) [24], the order fulfillment process consists of seven activities, which are order entry, order processing, manufacturing process, fill order, order delivery, customer receipt and post delivery activities.

A review is made on about twenty references concerning SC performance measurement. As nonfinancial measures are used when evaluating operational performance [8], the non-financial measures are reviewed and assigned to its related order fulfillment activities. Order fulfillment activities with a detailed description of their corresponding measures are shown in "Table 1".

Table 1. Detailed description for metrics of Order Fulfillment Activities (Internal measures)

\begin{tabular}{|c|c|c|c|}
\hline ACTIVITY & NO. & METRIC (UNIT) & DESCRIPTION \\
\hline \multirow[t]{3}{*}{ Order entry } & 1 & $\begin{array}{l}\text { Percentage of data } \\
\text { accuracy }(\%)[25]\end{array}$ & $\begin{array}{l}\text { The percentage of orders entered into the order } \\
\text { management system, which not contain errors (incorrect } \\
\text { address, product information or invoice data). }\end{array}$ \\
\hline & 2 & $\begin{array}{l}\text { Percentage of received } \\
\text { orders do not contain all } \\
\text { required information }(\%) \\
{[26]}\end{array}$ & $\begin{array}{l}\text { These orders might be due to an issue with the sales } \\
\text { process or with the customer. For instance, it might be } \\
\text { incomplete because the sales people are providing } \\
\text { customers with incomplete quotes. }\end{array}$ \\
\hline & 3 & $\begin{array}{l}\text { Order communication } \\
\text { cycle time(unit } \\
\text { time/order) [27] }\end{array}$ & $\begin{array}{l}\text { The average amount of time needed to communicate an } \\
\text { order internally, from the placement of the order by the } \\
\text { customer to entry into the company order management } \\
\text { system. }\end{array}$ \\
\hline \multirow[t]{5}{*}{$\begin{array}{c}\text { Order } \\
\text { processing }\end{array}$} & 1 & $\begin{array}{l}\text { Order processing cycle } \\
\text { time(unit time/order) [28] }\end{array}$ & $\begin{array}{l}\text { The average amount of time needed to process a } \\
\text { customer order, from entry into the company order } \\
\text { management system to the start of the next step. Next } \\
\text { step may be shipping to the customer or start production. }\end{array}$ \\
\hline & 2 & $\begin{array}{l}\text { Percentage of out of stock } \\
\text { items }(\%)[29]\end{array}$ & $\begin{array}{l}\text { This metric measures the percentage of raw material } \\
\text { items that are out of stock at the time a customer places } \\
\text { an order. }\end{array}$ \\
\hline & 3 & $\begin{array}{l}\text { On time delivery, supplier } \\
(\%)[30]\end{array}$ & $\begin{array}{l}\text { This metric indicates the percentage of orders that are } \\
\text { fulfilled by supplier on or before the requested date. }\end{array}$ \\
\hline & 4 & Supplier defect rate [31] & $\begin{array}{l}\text { Supplier defect rate measures the percentage of materials } \\
\text { received from suppliers that do not meet required quality. }\end{array}$ \\
\hline & 5 & $\begin{array}{l}\text { Order fill rate, supplier } \\
(\%)[31]\end{array}$ & $\begin{array}{l}\text { This metric measures the percentage of orders/lines that } \\
\text { are received complete from each supplier in the } \\
\text { measurement period. }\end{array}$ \\
\hline $\begin{array}{l}\text { Manufacturing } \\
\text { process }\end{array}$ & 1 & $\begin{array}{l}\text { Average manufacturing } \\
\text { cycle time(unit time } \\
\text { item) [32] }\end{array}$ & $\begin{array}{l}\text { Measures the average time it takes to manufacture an } \\
\text { item. Manufacturing cycle time includes all machines and } \\
\text { processes through which a product must pass to become a } \\
\text { finished product. }\end{array}$ \\
\hline
\end{tabular}




\begin{tabular}{|c|c|c|c|}
\hline & 2 & $\begin{array}{l}\text { Capacity utilization (\%) } \\
\text { [33] }\end{array}$ & $\begin{array}{l}\text { It is the relationship between actual output that is actually } \\
\text { produced with the installed equipment, and the } \\
\text { potential output which could be produced with it. }\end{array}$ \\
\hline & 3 & $\begin{array}{l}\text { Percent defective (\%) } \\
{[34]}\end{array}$ & $\begin{array}{l}\text { The percent defective of any given quantity of units of } \\
\text { the product is one hundred times the number of defective } \\
\text { units of the product contained therein divided by the total } \\
\text { number of units inspected. }\end{array}$ \\
\hline \multirow[t]{3}{*}{ Order filling } & 1 & $\begin{array}{l}\text { Percentage of late orders } \\
\text { duo to unavailability of } \\
\text { stock }(\%)[35]\end{array}$ & $\begin{array}{l}\text { The metric measures the portion of total orders that are } \\
\text { held and shipped late due to unavailability of stock. }\end{array}$ \\
\hline & 2 & $\begin{array}{l}\text { Average warehouse } \\
\text { capacity used }(\%)[30]\end{array}$ & $\begin{array}{l}\text { The metric measures the percentage of final product } \\
\text { warehouse capacity used over a specific amount of time. }\end{array}$ \\
\hline & 3 & $\begin{array}{l}\text { Order picking \& packing } \\
\text { accuracy }(\%)[35]\end{array}$ & $\begin{array}{l}\text { The metric measures the accuracy of order picking and } \\
\text { packing process. Errors may be caught prior to shipment. }\end{array}$ \\
\hline \multirow[t]{2}{*}{ Order delivery } & 1 & On time arrival (\%) [35] & $\begin{array}{l}\text { This is a measure of a percentage of late orders due to } \\
\text { transportation errors }\end{array}$ \\
\hline & 2 & $\begin{array}{l}\text { Shipped damage free }(\%) \\
{[6]}\end{array}$ & $\begin{array}{l}\text { The metric measures the percentage of customer orders } \\
\text { shipped in good and usable condition. }\end{array}$ \\
\hline $\begin{array}{l}\text { Customer } \\
\text { receipt }\end{array}$ & 1 & $\begin{array}{l}\text { Percentage of error free } \\
\text { receipts (\%) [36] }\end{array}$ & $\begin{array}{l}\text { This is a measure of a percentage of error-free customer } \\
\text { receipts. Errors may be incorrect installation, faultless } \\
\text { invoices, payment problems, etc. }\end{array}$ \\
\hline \multirow[t]{2}{*}{$\begin{array}{l}\text { Post delivery } \\
\text { activities }\end{array}$} & 1 & $\begin{array}{l}\text { Percentage of customer } \\
\text { returns fulfilled at the } \\
\text { agreed time (\%) [36] }\end{array}$ & $\begin{array}{l}\text { This is a measure of a percentage of returns quickly } \\
\text { processed and fulfilled within the promised time. }\end{array}$ \\
\hline & 2 & $\begin{array}{l}\text { Percentage of resolved } \\
\text { complaints }(\%)[37]\end{array}$ & $\begin{array}{l}\text { This is a measure of a percentage of customer complaints } \\
\text { handled and resolved. }\end{array}$ \\
\hline
\end{tabular}

\subsection{The second category (External measures)}

This category is developed according to output measures group which defined by Beamon and Benita (1999) [7]. Output measures aim to evaluate the level of customer satisfaction on the supply chain. The goal of this category is to measure the accuracy of the delivered orders as a main factor of customer satisfaction. The assigned measures to this category are listed and described in detail as shown in "Table 2".

\subsection{Determining the weights of measures}

As the needs of organizations can vary, it is important to consider that certain metrics have different importance to organizations. It is then significant to give these metrics an adaptable weight that would be likely to fit specific objectives. This step can be performed by a survey. The role of the participants is to express the degree of importance on a scale of 1 to 7 (1=not important to $7=$ very important)

\subsection{Determining the best, worst, average and current} performance of each measure

A supply chain department of the company has to indicate four values for each measure:

1) The best level, which is the performance targeted during the near future.

2) The worst level, which is the minimum accepted level of performance they would reach.

3) The average level, which is the average performance during the last specified period of time.

4) The current level, which is the level achieved presently. 
Table 2. Detailed description for metrics of accuracy of delivered orders (External measures)

\begin{tabular}{||c|l|l||}
\hline NO. & \multicolumn{1}{|c|}{ METRIC (UNIT) } & \multicolumn{1}{c|}{ DESCRIPTION } \\
\hline 1 & On-time delivery [38] & $\begin{array}{l}\text { The metric measures the percentage of orders } \\
\text { that arrive at their final destination at the agreed } \\
\text { upon time, or percentage of orders fulfilled on } \\
\text { the customer's requested date. }\end{array}$ \\
\hline 2 & Order fill rate, customer [25] & $\begin{array}{l}\text { The number of orders that are filled completely } \\
\text { relative to the total orders filled. }\end{array}$ \\
\hline 3 & Percentage of returns [39] & $\begin{array}{l}\text { For a certain period, how many units are } \\
\text { returned due to quality problems out of total } \\
\text { units delivered to customers. }\end{array}$ \\
\hline 4 & Correct documentation [6] & $\begin{array}{l}\text { The metric measures the percent of total orders } \\
\text { for which the customers received an accurate } \\
\text { invoice and other required documents as ASNs } \\
\text { (Advance Shipping Notes), invoices, etc. }\end{array}$ \\
\hline
\end{tabular}

\subsection{Objectives matrix [40]}

For the two previous categories of measures, the Objectives Matrix tool can be used to combine these measures in one overall performance index.

\subsubsection{Objectives matrix construction}

The objectives matrix has three main parts as shown in "Figure 6"which described as follow:

The upper part is divided into some columns; each one is dedicated to one of the performance measures. The middle part is divided into eleven rows, which indicate the levels of each measure. The bottom part is divided into four rows; the first one for the current value of each measure, the second for the nearest equivalent level for the current value, the third for the relative weight of each measure and the last row for the measure's score.

\subsubsection{Objectives Matrix Application}

The objectives matrix is filled as follows:

1) The average level of each measure through a specified period of time is put in the third level of the objectives matrix middle part. The third level is chosen to give more chances for improvements.

2) The best level of each measure is put in tenth level of the objectives matrix middle part then boxes filled from the third level to tenth level with equal intervals.
3) The worst level of each measure is put in zero level of the objectives matrix middle part then boxes filled from the third level to zero level with equal intervals.

4) The current performance that the company reaches for each measure is put in the first row of the bottom part and the nearest equivalent level to the current performance is put in the second row of the bottom part.

5) The relative weight of each measure is put in the third row of the bottom part.

\begin{tabular}{|c|c|c|c|}
\hline Measures & A & B & C \\
\hline
\end{tabular}

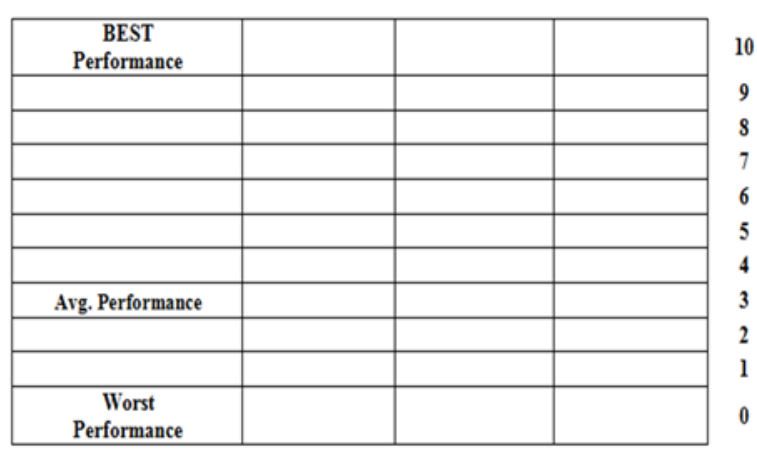

\begin{tabular}{|c|l|l|l|}
\hline $\begin{array}{c}\text { Current } \\
\text { Performance }\end{array}$ & & & \\
\hline Equivalent Level & & & \\
\hline Weight & & & \\
\hline Score & & & \\
\hline
\end{tabular}

Fig. 6. Objectives matrix construction [40] 
6) The score is calculated for each measure by multiplying the equivalent level of the measure by the weight of that measure.

7) Finally, the performance index is calculated by adding the scores of all measures. Then divide the performance index by the best performance index to get the relative performance index.

\section{Case Study}

For applying the proposed performance measurement framework, a leading sports apparel company is selected with assumed name X. X company is a subsidiary of a worldwide Turkish company. This Turkish company has a strategic partnership with NIKE, which is an international leading apparel brand.

X Company is located in 10th of Ramadan, Egypt and specialized in producing and exporting sport $\mathrm{T}$ shirts with different styles and sizes.

NIKE is regarded the customer in this case and the textile supplier is the Turkish company. The product under study in this case is a printed sport T-shirt.

The X Company's supply chain department is asked to indicate four values for each measure which are: best level, worst level, average level (six month measurement period) and current level (three month measurement period).

It is found that four measures of the first category and one measure of the second category are inapplicable in X Company:

1) Percentage of out of Stock Items is inapplicable as the policy pursued by NIKE international company is sending the order to the Turkish company early enough and Turkish company has to send the required textile to $\mathrm{X}$ Company in advance one week.

2) On Time Delivery, Supplier is inapplicable as the same reason of the previous measure.

3) Percentage of Late Orders Duo to Unavailability of Stock is inapplicable as X Company applies MTO (Make to Order) strategy.

4) Percentage of Customer Returns Fulfilled at the Agreed Time is inapplicable as there are no defective products returned to X Company because the produced $\mathrm{T}$-shirts are fully inspected and the inspector is certified by NIKE.

5) Percentage of returns is inapplicable as the same reason of the previous measure.

The corresponding weight for each measure is determined through a survey that conducted by distributing a designed questionnaire on a thirty textile company which located in 10th of Ramadan city in Egypt. This sample size was considered enough to achieve the goal of the research by getting a casual trend of the measures weights. Filling the questionnaire was done through direct discussion (interviews) with the supply chain manager of each company.

The degree of each measure is computed by averaging the viewpoints. These degrees of importance are transformed into relative weights by dividing each degree by the summation of all measures degrees in each category. The summation of the degrees of each category is calculated after exclusion of inapplicable measures.

The first objectives matrix that constructed for the first category is shown in "Table 3". The second one that constructed for the second category is shown in "Table 4".

\section{Results}

From the first objectives matrix: Internal Performance Index $=\sum$ Score $=$ $\sum($ Equivalent Score $\times$ Weight $)=639$

For The Best Performance, Performance Index (Best Performance Index) $=1000$

Relative Internal Performance Index

$=\left(\sum\right.$ Score $/$ Best Performance Index $)$

$=0.6493 \rightarrow 63.9 \%$

From the second objectives matrix: External Performance Index $=\sum$ Score $=$ $\sum($ Equivalent score $\times$ weight $)=592$

Relative External Performance Index $=$ $0.6276 \rightarrow 59.2 \%$

The Relative Internal Performance Index indicates the overall performance of order fulfillment activities and the Relative External Performance Index indicates the overall accuracy of the delivered orders, which represents the main purpose of order fulfillment process. These indices can represent a current level of performance that needs to be improved.

\section{Conclusions}

From the objectives matrices, it is found that the values of the Relative Internal Performance Index and Relative External Performance Index are relatively low compared to the best performance. So, these indices can represent a current level of performance 
that needs to be improved. Then the measures that get low equivalent scores and also highly weighted should be analyzed and the causes of problems have to be solved or eliminated. In this case, the measures that need to be improved in the first category are Average manufacturing cycle time, Percent defective, Capacity utilization and Supplier defect rate. Also, in the second category there are two measures need to be improved which are on time delivery and order fill rate, customer. After improving the previous measures, the future performance indices could be measured again and the improvement in activities and accuracy of the delivered orders can be evaluated.

From the performed questionnaire it is concluded that many measures of the proposed framework are not significant in textile industry in Egypt, which get low weights such as Order Communication Cycle Time, Percentage of Error Free Receipts, Percentage of Received Orders Do Not Contain All Required Information, Shipped Damage Free, Order Picking \& Packing Accuracy and Correct Documentation.

The proposed framework is regarded a good way of measuring order fulfillment process performance in supply chain as it concentrates on the performance of all activities done during fulfilling customer orders through supply chain and also concentrates on the accuracy of the delivered orders as the major supply chain purpose.

\section{References}

[1] Peng Wong, Wai, and Kuan Yew Wong. "Supply chain performance measurement system using DEA modeling." Industrial Management \& Data Systems 107.3 (2007): 361-381.

[2] Giunipero, Larry C., and Richard R. Brand. "Purchasing's role in supply chain management." The International Journal of Logistics Management 7.1 (1996): 29-38.

[3] Beamon, Benita M., and Tonja M. Ware. "A process quality model for the analysis, improvement and control of supply chain systems." International Journal of Physical Distribution \& Logistics Management 28.9/10 (1998): 704-715.

[4] Chandra, Charu, and Sameer Kumar. "Supply chain management in theory and practice: a passing fad or a fundamental change?." Industrial Management \& Data Systems 100.3 (2000): 100-114.

[5] Cooper, Martha C., Douglas M. Lambert, and Janus D. Pagh. "Supply chain management: more than a new name for logistics." The international journal of logistics management 8.1 (1997): 1-14.

[6] Pochampally, Kishore K., Surendra M. Gupta, and Kannan Govindan. "Metrics for performance measurement of a reverse/closed-loop supply chain." International Journal of Business Performance and Supply Chain Modelling 1.1 (2009): 8-32.

[7] Beamon, Benita M. "Measuring supply chain performance." International Journal of Operations \& Production Management 19.3 (1999): 275-292.

[8] Sillanpaa, Ilkka, and Pekka Kess. "Supply chain performance measurement framework for manufacturing industries-a theoretical approach." MIC 2011: Managing Sustainability?
Proceedings of the 12th International Conference, Portorož, 23-26 November 2011 [Selected Papers]. University of Primorska, Faculty of Management Koper, 2011.

[9] Otto, Andreas, and Herbert Kotzab. "Does supply chain management really pay? Six perspectives to measure the performance of managing a supply chain." European Journal of Operational Research 144.2 (2003): 306-320.

[10] Najmi, Ali, Mohammad Reza Gholamian, and Ahamad Makui. "Supply chain performance models: A literature review on approaches, techniques, and criteria." Journal of Operations and Supply Chain Management 6.2 (2013): 94113.

[11] Ghalayini, Alaa M., and James S. Noble. "The changing basis of performance measurement." International Journal of Operations \& Production Management 16.8 (1996): 63-80.

[12] De Toni, Alberto, and Stefano Tonchia. "Performance measurement systems-models, characteristics and measures." International Journal of Operations \& Production Management 21.1/2 (2001): 46-71.

[13] Chan, Felix TS, and H. J. Qi. "Feasibility of performance measurement system for supply chain: a process-based approach and measures."Integrated manufacturing systems 14.3 (2003a): 179-190.

[14] Chan, Felix TS, and Han J. Qi. "An innovative performance measurement method for supply chain management." Supply chain management: An international Journal 8.3 (2003b): 209-223.

[15] Gunasekaran, Angappa, Christopher Patel, and Ronald E. McGaughey. "A framework for supply chain performance measurement." International journal of production economics 87.3 (2004): 333-347.

[16] Shepherd, Craig, and Hannes Günter. "Measuring supply chain performance: current research and future directions." Behavioral Operations in Planning and Scheduling. Springer Berlin Heidelberg, 2011. 105-121.

[17] Chan, Felix TS. "Performance measurement in a supply chain." The international journal of advanced manufacturing technology 21.7 (2003): 534-548.

[18] Theeranuphattana, Adisak, and John CS Tang. "A conceptual model of performance measurement for supply chains: alternative considerations."Journal of Manufacturing Technology Management 19.1 (2008): 125-148.

[19] Kaplan RS and Norton DP. "The Balanced Scorecard Measures That Drive Performance." Harvard Business Review January-February (1992): 71.

[20] Kaplan, Robert S., and David P. Norton. "Putting the Balanced Scorecard to work." Focus Your Organization on Strategy —with the Balanced Scorecard (2000): 14.

[21] Kaplan, Robert S., and David P. Norton. "Using the balanced scorecard as a strategic management system." (1996).

[22] Neely, Andy, Mike Gregory, and Ken Platts. "Performance measurement system design: a literature review and research agenda." International journal of operations \& production management 25.12 (2005): 1228-1263.

[23] Bhagwat, Rajat, and Milind Kumar Sharma. "Performance measurement of supply chain management: A balanced scorecard approach." Computers \& Industrial Engineering 53.1 (2007): 43-62.

[24] Amer, Yousef, Lee Luong, Sang-Heon Lee, and M. Azeem Ashraf. "Optimizing order fulfillment using design for six sigma and fuzzy logic."International Journal of Management Science and Engineering Management3, no. 2 (2008): 83-99.

[25] McGladrey Manufacturing and Distribution Monitor survey (2014). Available from: https://opsdog.com/industries/ordermanagement/order-management-kpis-and-benchmarks, last accessed: December 12, 2014

[26] Waller, Matthew A., Dennis Woolsey, and Robert Seaker. "Reengineering order fulfillment." The International Journal of Logistics Management 6.2 (1995): 1-10. 
Table 3. Objectives matrix of internal measures

\begin{tabular}{|c|c|c|c|c|c|c|c|c|c|c|c|}
\hline 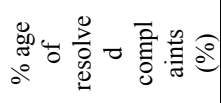 & $\Xi$ & 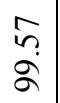 & $\frac{ \pm}{a}$ & $\underset{\infty}{\stackrel{\infty}{a}}$ & సे & 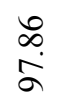 & $\stackrel{?}{\stackrel{?}{a}}$ & $\hat{a}$ & ஸి? & $\begin{array}{l}\hat{b} \\
\dot{a}\end{array}$ & $\dddot{\alpha}$ \\
\hline 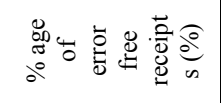 & $\Xi$ & 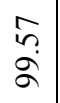 & $\frac{7}{2}$ & $\underset{\hat{\infty}}{\vec{\infty}}$ & $\begin{array}{l}\stackrel{\text { ते }}{\infty} \\
\infty\end{array}$ & $\begin{array}{l}0 \\
\infty \\
\vdots \\
\vdots\end{array}$ & 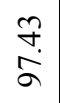 & $\hat{a}$ & $\begin{array}{l}\hat{\sigma} \\
\dot{0}\end{array}$ & 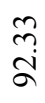 & 8 \\
\hline 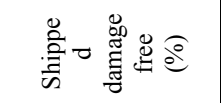 & $\stackrel{8}{\varrho}$ & $\hat{\alpha}$ & $\begin{array}{l}\circ \\
\infty\end{array}$ & $\stackrel{\hat{\sigma}}{a}$ & 형 & $\begin{array}{l}\text { ț } \\
\stackrel{2}{\sigma}\end{array}$ & $\begin{array}{l}\hat{n} \\
\alpha\end{array}$ & ณุ & $\begin{array}{l}\text { m. } \\
\stackrel{2}{a}\end{array}$ & 今 & à \\
\hline 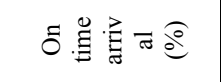 & 0 & $\hat{0}$ & $\frac{\Delta}{0}$ & $\vec{\jmath}$ & तु & $\begin{array}{l}0 \\
m \\
0\end{array}$ & $\stackrel{?}{\circ}$ & $\dddot{n}$ & $\hat{0}$ & $\begin{array}{c}\infty \\
\infty \\
0\end{array}$ & - \\
\hline 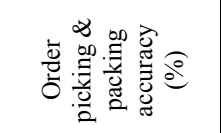 & $\Xi$ & $\vec{a}$ & 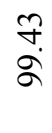 & $\frac{ \pm}{a}$ & $\begin{array}{l}\infty \\
\infty \\
\infty \\
\infty\end{array}$ & $\begin{array}{l}n \\
n \\
\infty\end{array}$ & $\begin{array}{c}\stackrel{i}{1} \\
\infty\end{array}$ & $\mathscr{a}$ & $\begin{array}{l}\hat{b} \\
\hat{a}\end{array}$ & $\stackrel{m}{a}$ & $\hat{a}$ \\
\hline 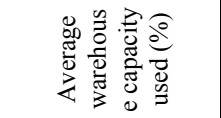 & 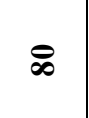 & $\begin{array}{l}n \\
\infty \\
\infty \\
\infty\end{array}$ & $\underset{\frac{1}{2}}{\stackrel{5}{2}}$ & i & $\stackrel{\text { Tे }}{+}$ & $\begin{array}{l}\infty \\
\infty \\
i \\
i\end{array}$ & $\stackrel{?}{\stackrel{P}{i}}$ & $R$ & $\begin{array}{l}0 \\
0 \\
0\end{array}$ & $\overbrace{\hat{\sigma}}^{\text {ते }}$ & 8 \\
\hline 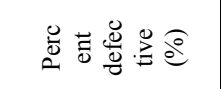 & - & $\vec{n}$ & $\ddot{i}$ & $\tilde{n}$ & $\underset{\text { Oे }}{\dot{m}}$ & $\stackrel{n}{n}$ & $\underset{\sim}{\mathscr{\sigma}}$ & $\underset{r}{i}$ & $\hat{n}$ & $\sqrt[n]{n}$ & 0 \\
\hline 胥: & $\approx$ & $\stackrel{?}{\stackrel{?}{2}}$ & $\begin{array}{l}\infty \\
\infty \\
\infty \\
\infty\end{array}$ & 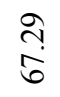 & $\underset{8}{i b}$ & $\underset{⿱}{ \pm}$ & $\begin{array}{l}n \\
i \\
\text { in }\end{array}$ & $\overline{6}$ & in & in & in \\
\hline 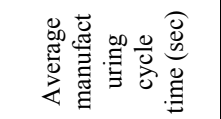 & $\nabla$ & $\begin{array}{l}\tilde{n} \\
\tilde{\sigma} \\
\dot{\sigma}\end{array}$ & $\hat{\dot{\sigma}}$ & $\stackrel{n}{\varrho}$ & $\underset{+}{\stackrel{9}{+}}$ & $\stackrel{n}{\stackrel{2}{\sigma}}$ & $\vec{\sim}$ & $\stackrel{\substack{f \\
\hdashline}}{+}$ & $\stackrel{m}{\dddot{\sim}}$ & $\stackrel{n}{f}$ & $\stackrel{?}{q}$ \\
\hline 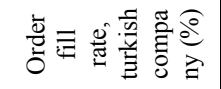 & ฉे & $\stackrel{\infty}{\sigma}$ & $\hat{a}$ & ๙ & $\approx$ & $\sigma$ &  & $\tilde{\alpha}$ & \& & $\infty$ & $\infty$ \\
\hline 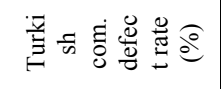 & 0 & $\stackrel{ \pm}{\circ}$ & సे & $\stackrel{?}{\circ}$ & $n$ & $\vec{\pi}$ & $\begin{array}{l}\infty \\
\infty \\
0\end{array}$ & - & $\stackrel{\hat{\sigma}}{-}$ & $\stackrel{m}{i}$ & $m$ \\
\hline 旁 & in & $\begin{array}{l}\tilde{b} \\
\dot{r}\end{array}$ & స్ & $\begin{array}{l}\infty \\
\infty \\
0\end{array}$ & 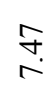 & $\begin{array}{l}a \\
\infty \\
\infty\end{array}$ & $\underset{\infty}{\infty}$ & $\stackrel{m}{a}$ & $\stackrel{\square}{\circ}$ & $\hat{\varrho}$ & $\stackrel{\infty}{=}$ \\
\hline 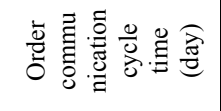 & $N$ & $\stackrel{a}{\vec{i}}$ & $\hat{n}$ & $\stackrel{\circ}{n}$ & $\stackrel{n}{i}$ & $\stackrel{t}{i}$ & $\stackrel{7}{m}$ & $\vec{m}$ & $\stackrel{\infty}{\stackrel{\infty}{r}}$ & $\stackrel{\bullet}{\stackrel{+}{+}}$ & $\stackrel{?}{+}$ \\
\hline 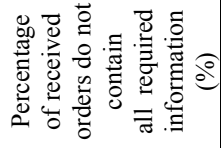 & 0 & $\stackrel{ \pm}{0}$ & ते & $\stackrel{n}{0}$ & $\hat{n}$ & $\overrightarrow{0}$ & $\begin{array}{l}0 \\
\infty \\
0\end{array}$ & - & $m$ & in & $r$ \\
\hline 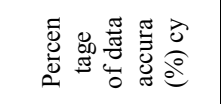 & 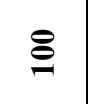 & $\begin{array}{l}\text { ते } \\
\text { ू̆ }\end{array}$ & $\begin{array}{l}n \\
n \\
\infty\end{array}$ & $\begin{array}{l}\stackrel{2}{\infty} \\
\stackrel{\infty}{a}\end{array}$ & $\underset{⿱ 亠 䒑}{a}$ & $\underset{\stackrel{q}{q}}{\stackrel{8}{q}}$ & $\vec{i}$ & $\ltimes 2$ & $\frac{\hat{\sigma}}{\dot{\sigma}}$ & $\begin{array}{c}m \\
m \\
\infty \\
\infty\end{array}$ & $\infty$ \\
\hline 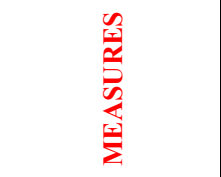 & 莺 & & & & & & & 苋 & & & 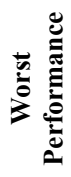 \\
\hline
\end{tabular}

\begin{tabular}{|c|c|c|c|}
\hline 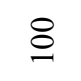 & 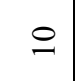 & $\frac{\partial}{\dot{n}}$ & $\frac{\sigma}{n}$ \\
\hline 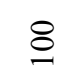 & $\circ$ & $\stackrel{\infty}{\stackrel{\infty}{m}}$ & 㐫 \\
\hline 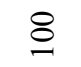 & $\circ$ & $\stackrel{+}{+}$ & F \\
\hline 0 & 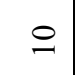 & $\hat{\alpha}$ & ìn \\
\hline  & 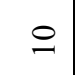 & $\stackrel{\stackrel{n}{+}}{+}$ & $\stackrel{n}{7}$ \\
\hline$\stackrel{n}{2}$ & 0 & mi & $\bar{i}$ \\
\hline$\underset{\dot{r}}{\vec{r}}$ & $\nabla$ & $\overline{0}$ & +े \\
\hline$\hat{\beta}$ & $\nabla$ & aे & $\begin{array}{l}\infty \\
\infty \\
\infty \\
m\end{array}$ \\
\hline$\underset{\stackrel{f}{\sim}}{\stackrel{f}{+}}$ & $\sim$ & $\hat{n}$ & $\hat{\tilde{d}}$ \\
\hline 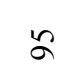 & 0 & 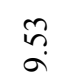 & $\underset{n}{i n}$ \\
\hline $\begin{array}{l}n \\
0 \\
0\end{array}$ & $n$ & $\underset{\sigma}{\stackrel{t}{a}}$ & $\hat{\infty}$ \\
\hline$\infty$ & $n$ & $\bar{\alpha}$ & 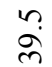 \\
\hline$\stackrel{n}{i}$ & $r$ & $\begin{array}{l}\tilde{O} \\
\dot{r}\end{array}$ & $\begin{array}{l}\infty \\
\stackrel{0}{0}\end{array}$ \\
\hline 0 & ㅇ & $\stackrel{n}{m}$ & $\ddot{r}$ \\
\hline 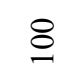 & 인 & $\frac{m}{m}$ & $\frac{m}{n}$ \\
\hline 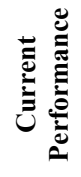 & 竧 & $\begin{array}{l}\vec{E} \\
\frac{\vec{b}}{\vec{E}} \\
\vec{z}\end{array}$ & 竎 \\
\hline
\end{tabular}


Table 4. Objectives matrix of external measures

\begin{tabular}{|c|c|c|c|}
\hline Measures & $\begin{array}{c}\text { On-time } \\
\text { delivery }\end{array}$ & $\begin{array}{c}\text { Order fill } \\
\text { rate, } \\
\text { customer }\end{array}$ & $\begin{array}{c}\text { Correct } \\
\text { documentation }\end{array}$ \\
\hline
\end{tabular}

\begin{tabular}{|c|c|c|c|}
\hline $\begin{array}{c}\text { BEST } \\
\text { Performance }\end{array}$ & 100 & 100 & 100 \\
\hline & 98.55 & 98.29 & 99.86 \\
\hline & 97.11 & 96.57 & 99.71 \\
\hline & 95.66 & 94.86 & 99.57 \\
\hline & 94.21 & 93.14 & 99.43 \\
\hline & 92.76 & 91.43 & 99.29 \\
\hline & 91.32 & 89.71 & 99.14 \\
\hline \multirow[t]{3}{*}{ Avg. Performance } & 89.87 & 88 & 99 \\
\hline & 86.58 & 83.67 & 97.67 \\
\hline & 83.29 & 79.33 & 96.33 \\
\hline $\begin{array}{c}\text { Worst } \\
\text { Performance }\end{array}$ & 80 & 75 & 95 \\
\hline
\end{tabular}

\begin{tabular}{|c|c|c|c|}
\hline $\begin{array}{c}\text { Current } \\
\text { Performance }\end{array}$ & 91.69 & 91.66 & 100 \\
\hline Equivalent level & 4 & 5 & 10 \\
\hline Weight & 38.31 & 35.63 & 26.05 \\
\hline Score & 153.3 & 178.2 & 260.5 \\
\hline
\end{tabular}

[27] Maskell, Brian H., Bruce Baggaley, and Larry Grasso. "Practical lean accounting: a proven system for measuring and managing the lean enterprise". CRC Press, 2011.

[28] Rummler, Geary A., and Alan P. Brache. "Improving performance: How to manage the white space on the organization chart". John Wiley \& Sons, 2012.

[29] Wisner, Joel, Keah-Choon Tan, and G. Leong."Principles of supply chain management: a balanced approach". Cengage Learning, 2015.

[30] Ecklund, David K. "Warehousing Efficiency and Effectiveness in the Supply Chain Process". Supply Chain Management Review. 15 Oct. 2010. Web. 24 May 2012.

[31] Klapper, Larry S., et al. "Supply chain management: a recommended performance measurement scorecard". No. LMI-LG803R1. LOGISTICS MANAGEMENT INST MCLEAN VA, 1999.

[32] Gunasekaran, Angappa. "Agile manufacturing: a framework for research and development." International journal of production economics 62.1 (1999): 87-105.

[33] Mark Davidson (2013). LNS research. Available from:http://blog.lnsresearch.com/Blog/Bid/188295/28Manufacturing-Metrics-That-Actually-Matter-The-Ones-WeRely-On. Last accessed: December 20, 2014.
[34] Basu, Ron, and J. Nevan Wright."Total supply chain management". Routledge, 2010.

[35] Vitasek K. "Warehousing \& Fulfillment Process Benchmark and Best Practices Guide".

[36] Aronovich, D., Tien, M., Collins, E., Sommerlatte, A. and Allain, L. "Measuring Supply Chain Performance: Guide to Key Performance Indicators for Public Health Managers". Arlington, Va.: USAID, DELIVER PROJECT, Task Order, 2010

[37] REM Associates. "Customer Service Management and Benchmarking: Standards for Excellence". Princeton, New Jersey, June 1999.

[38] Croxton, Keely L., et al. "The supply chain management processes." The International Journal of Logistics Management 12.2 (2001): 13-36.

[39] Lambert, Douglas M. "Supply chain management: processes, partnerships, performance". Supply Chain Management Inst, 2008.

[40] Riggs, J.L. "Monitoring with a Matrix that Motivates as it Measures". Industrial Engineering, 18(1), p.34, 1986. 